\title{
Mansonella ozzardi (Nematoda: Onchocercidae) in the riverine population of the Tefé River, State of Amazonia, Brazil
}

\author{
Jansen Fernandes Medeiros ${ }^{[1]}$, Cristóvão Alves Costa ${ }^{[2]}$, Alita Moura de Lima ${ }^{[2]}$ \\ and Felipe Arley Costa Pessoa ${ }^{[3]}$
}

[1]. Laboratório de Entomologia Médica, Fundação Oswaldo Cruz, Porto Velho, RO. [2]. Coordenação de Sociedade, Ambiente e Saúde, Instituto Nacional de Pesquisas da Amazônia, Manaus, AM. [3]. Instituto Leônidas e Maria Deane, Fundação Oswaldo Cruz, Manaus, AM.

\begin{abstract}
Introduction: This study assessed the prevalence of Mansonella ozzardi in riverine communities of the Tefé River, Amazonas, Brazil. Methods: The prevalence of $M$. ozzardi was estimated by microscopic examination of thick blood smears. Results: The M. ozzardi prevalence rate was 6.3\% (19/300). Filarial infection was found in 8 of the 11 communities surveyed, with prevalence rates varying from $2.5 \%$ to $22.2 \%$. Conclusions: Tefé is a region of oil and natural gas exploration, in which there is a high turnover of workers. Migration patterns may facilitate the dissemination of mansonelliasis to other regions.
\end{abstract}

Keywords: Mansonella ozzardi. Tefé River. Amazonas.

An epidemiological survey of mansonelliasis was conducted in Tefé, State of Amazonas, Brazil, in the 1950s and reported a prevalence rate between $2.5 \%$ and $18.7 \%$ for Mansonella ozzardi $i^{1}$. However, no other surveys have been conducted in this region, and current knowledge pertaining to the occurrence of mansonelliasis is based on records from the Foundation Surveillance Health (FVS) in Tefé obtained during a routine malaria survey (JF Medeiros: personal information). In Tefé, there is a significant population of migrant workers who are employed at companies that extract oil and natural gas. These companies employ many workers from regions without mansonelliasis, and this migration demonstrates the potential for the spread of mansonelliasis to non-endemic regions when these migrant workers return to their native communities. This study was the first survey of human filarial mansonelliasis in the Tefé River region of oil and gas production, and it was conducted to investigate the prevalence of $M$. ozzardi among the resident population of the Tefé River region.

The present study was conducted among people living along the Tefé River in the municipality of Tefé ( $\left.3^{\circ} 30^{\prime} \mathrm{S} 64^{\circ} 58^{\prime} \mathrm{W}\right)$, State of Amazonas, Brazil. The Tefé River, a tributary of the Solimões River, is an area rich in oil and gas, with continuous mineral extraction (Figure 1). The population density of the area is low, and the people live in small communities dispersed along the riverbanks and generally practice subsistence farming (fishing and agriculture).

Address to: Dr. Jansen Fernandes Medeiros. Lab. Entomologia Médica/ FIOCRUZ Rondônia. Rua da Beira 7671, Bairro Lagoa, 76812-245 Porto Velho, RO, Brasil.

Phone: 5569 3219-6011

e-mail: jmedeiro@gmail.com

Received 19 October 2012

Accepted 15 February 2013
The work presented here was part of a pilot study to provide baseline data for the design of future, more detailed studies. Individuals present at the initiation of the study were informed of the purpose and scope of the study and were invited to participate. Informed verbal consent to participate in the study was obtained from adult participants and the parents of child participants during community meetings. According to the Foundation of Surveillance in Health in Tefé, the population along the Tefe River numbers approximately 850 . A total of 300 individuals ( $\sim 35 \%$ of the population) between the ages of 2 and 82 years were included in this study and examined by rapid epidemiological mapping for microfilariae of M. ozzardi in June 2012. This study received approval from the Ethical Committee of the Tropical Medicine Foundation (Doutor Heitor Vieira Dourado (1504/2010), Manaus, State of Amazonas , Brazil).

The prevalence of Mansonella ozzardi was estimated using thick blood smears obtained by digital puncture. Four drops of blood (approximately 80 $\mu$ l) were collected from each participant and placed on a slide. After air-drying, the blood was dehemoglobinized, stained with a rapid panotic kit ${ }^{\circledR}$, and examined microscopically (200X) to identify the species of microfilariae present, according to the method of Orihel and Eberhard ${ }^{2}$. A comparison of the prevalence between sexes was performed using Yates corrected $\chi^{2}$ test with the Open Epi program.

A total of 300 people were examined, and 19 (6.3\%) were found to be infected with microfilariae of Mansonella ozzardi. M. ozzardi infections were found in 8 of the 11 communities examined. The prevalence rates ranged from $0 \%$ in Piraruaia, Mureketau, and Cacautuba to $22.2 \%$ in Santa Cruz; the lower prevalence rates were observed predominantly in the communities located in the lower Tefé River, near the mouth of the river. The microfilarial infection rate was found to be $7.9 \%$ among the 138 male subjects and $4.9 \%$ among the 162 female subjects. No significant between-gender difference was detected in our study $\left(\chi^{2}=0.701 \mathrm{p}=0.403\right)$ (Table 1). 


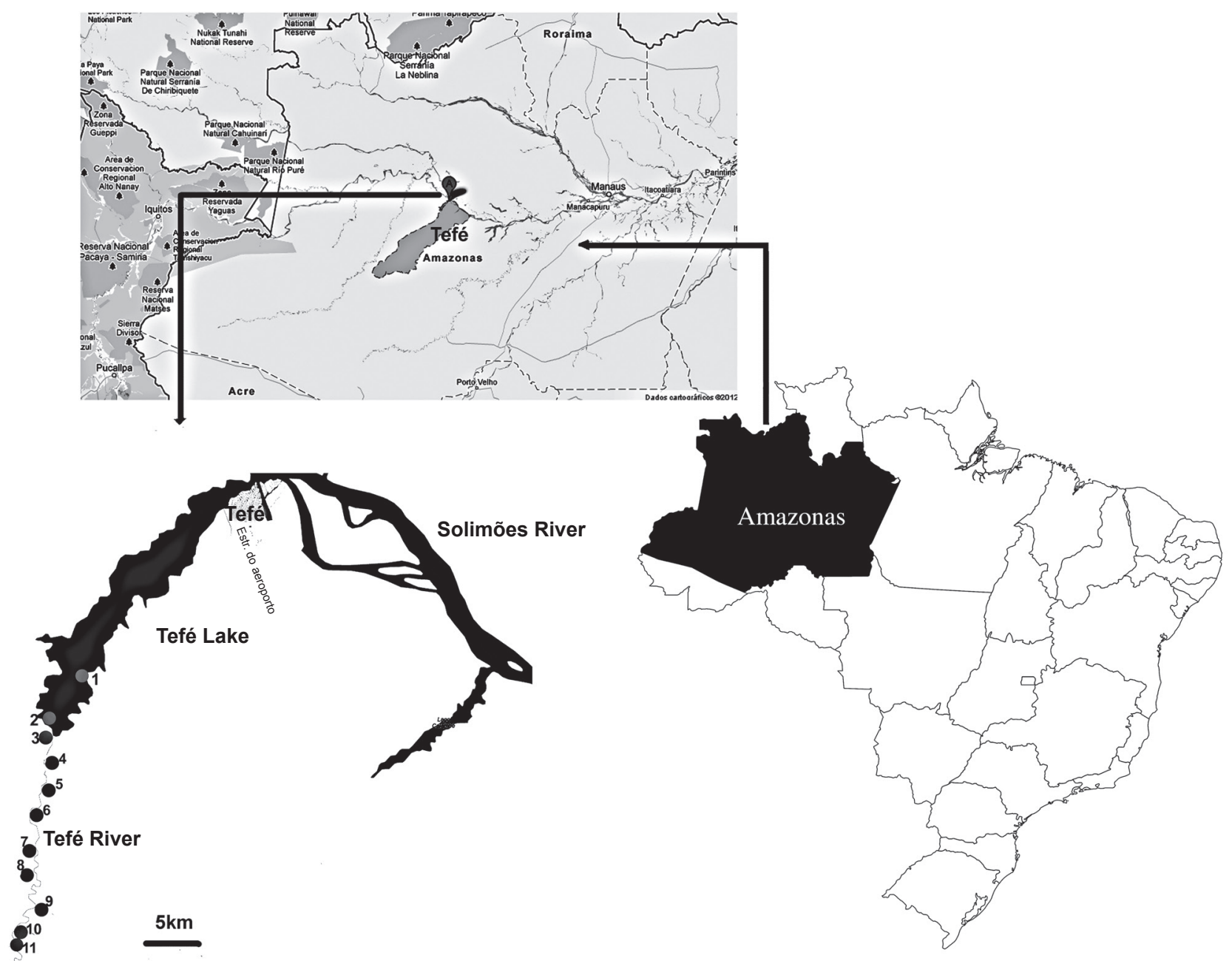

FIGURE 1 - Location of the riverine communities along the Tefé River, municipality of Tefé, State of Amazonas, Brazil.

1: Piraruaia; 2: Tauari; 3: Muquental; 4: São Raimundo do Sapiá; 5: Paxiubinha; 6: Aranatuba; 7: Deus é Pai; 8: Cacautuba; 9: Itaituba; 10: Boa Vista; 11: Santa Cruz.

This study revealed a wide distribution of this filarial parasite in the middle Solimões region and in the high tributaries of the Solimões basin. The $M$. ozzardi prevalence rates were lower (6.3\%) than those previously recorded in Solimões River communities, including rates of $23.9 \%$ in Codajás, 10.0 to $17.8 \%$ in Coari, 2.5 to $18.7 \%$ in Tefé, and 18.4 to $18.9 \%$ in Coari ${ }^{1,3,4}$. In addition, the communities located beside the middle and upper segments of the river presented a higher frequency of M. ozzardi infections, which was possibly related to the greater abundance of black fly vectors. In particular, this part the river is narrower and has a higher water velocity, which benefits the maintenance of insect breeding sites compared to the lower region, which is dammed by the lake. No significant difference among genders was detected, although males showed a slightly higher prevalence of mansonelliasis than females. These similar prevalence rates could be the result of similar exposure levels between sexes. In addition, our results are in agreement with those of Batista et al. ${ }^{5}$, Shelley ${ }^{6}$, and Medeiros et al. ${ }^{7}$, who found no statistically significant difference in the prevalence rates between sexes. However, other epidemiological studies have reported a higher disparity between the prevalence rates in males and females ${ }^{4,8}$.

The current study confirmed the presence of mansonelliasis in Tefé River communities near the major oil and natural gas production region. Epidemiological surveys also revealed a high population of black flies in these communities. These results should serve as an alert for the possibility of dissemination of this disease outside its natural focus due to non-resident employee turnover (non-infected). Moreover, the return of these employees to their original communities may further promote the appearance of new foci for mansonelliasis.

\section{ACKNOWLEDGMENTS}

The authors acknowledge the Fundação de Vigilância em Saúde de Tefé for logistical support. We thank José Jonas Nascimento da Rocha, Ricardo de Moura Mota, and Elbion de Oliveira Moraes for assistance during the fieldwork. Dr. James Lee Crayney and an anonymous referee reviewed the English. 
TABLE 1 - Mansonella ozzardi infections according to gender, total number, and percentage in communities along the Tefé River, Tefé, State of Amazonas, Brazil.

\begin{tabular}{|c|c|c|c|c|c|c|c|c|c|c|}
\hline Communities & $\begin{array}{c}\text { Total } \\
\text { population* }\end{array}$ & \multicolumn{3}{|c|}{ Males } & \multicolumn{3}{|c|}{ Females } & \multicolumn{3}{|c|}{ Total } \\
\hline Piraruaia & 132 & 22 & 0 & 0.0 & 22 & 0 & 0.0 & 44 & 0 & 0.0 \\
\hline Tauari & 80 & 15 & 1 & 6.7 & 10 & 0 & 0.0 & 25 & 1 & 4.0 \\
\hline Muquental & 83 & 11 & 0 & 0.0 & 12 & 0 & 0.0 & 23 & 0 & 0.0 \\
\hline Paxiubinha & 38 & 9 & 3 & 33.3 & 14 & 2 & 14.3 & 23 & 5 & 21.7 \\
\hline Aranatuba & 53 & 15 & 3 & 20.0 & 13 & 2 & 15.4 & 28 & 5 & 7.8 \\
\hline Deus é Pai & 70 & 27 & 2 & 7.4 & 35 & 1 & 2.8 & 62 & 3 & 4.9 \\
\hline Cacautuba & 33 & 6 & 0 & 0.0 & 11 & 0 & 0.0 & 17 & 0 & 0.0 \\
\hline Total & & 138 & 11 & 7.9 & 162 & 8 & 4.9 & 300 & 19 & 6.33 \\
\hline
\end{tabular}

Prev \%: prevalence; *Source: Foundation of Surveillance in Health.

\section{CONFLICT OF INTEREST}

The authors declare that there is no conflict of interest.

\section{FINANCIAL SUPPORT}

Financial support was provided by the Fundação de Amparo à Pesquisa do Estado do Amazonas (FAPEAM).

\section{REFERENCES}

1. Rachou RG. Distribuição geográfica das filarioses humanas no Brasil. Rev Bras Malariol Doencas Trop 1957; 9:79-100.

2. Orihel TC, Eberhard ML. Mansonella ozzardi: a rediscription with comments on its taxonomic relationships. Am J Trop Med Hyg 1982; 31:1142-1147.
3. Cohen JM, Ribeiro JAS, Martins M. Acometimento ocular em pacientes com mansonelose. Arq Bras Oftalmol 2008; 71:167-171.

4. Martins M, Pessoa FAC, Medeiros MB, Andrade EV, Medeiros JF. Mansonella ozzardi in Amazon, Brazil: prevalence and distribution in the municipality of Coari, in the middle Solimões River. Mem Inst Oswaldo Cruz 2010; 105:246-253.

5. Batista D, Cerqueira NL, Moraes MAP. Epidemiologia da mansonelose em localidade do interior do Amazonas. Rev Assoc Med Bras 1960; 6:176-184.

6. Shelley AJ. A preliminary survey of the prevalence of Mansonella ozzardi in some rural communities on the river Purus, state of Amazonas, Brazil. Ann Trop Med Parasitol 1975; 69:407-412.

7. Medeiros JF, Py-Daniel V, Barbosa VE, Ogawa GM. Current profile of Mansonella ozzardi (Nematoda: Onchocercidae ) in communities along the Ituxi river, Labrea municipality, Amazonas Brazil. Mem Inst Oswaldo Cruz 2008; 103:409-411.

8. Medeiros JF, Py-Daniel V, Barbosa UC. Mansonella ozzardi in Brazil: prevalence of infection in riverine communities in the Purus region, in the state of Amazonas. Mem Inst Oswaldo Cruz 2009; 104:74-80. 